\title{
Haemophilus influenzae
}

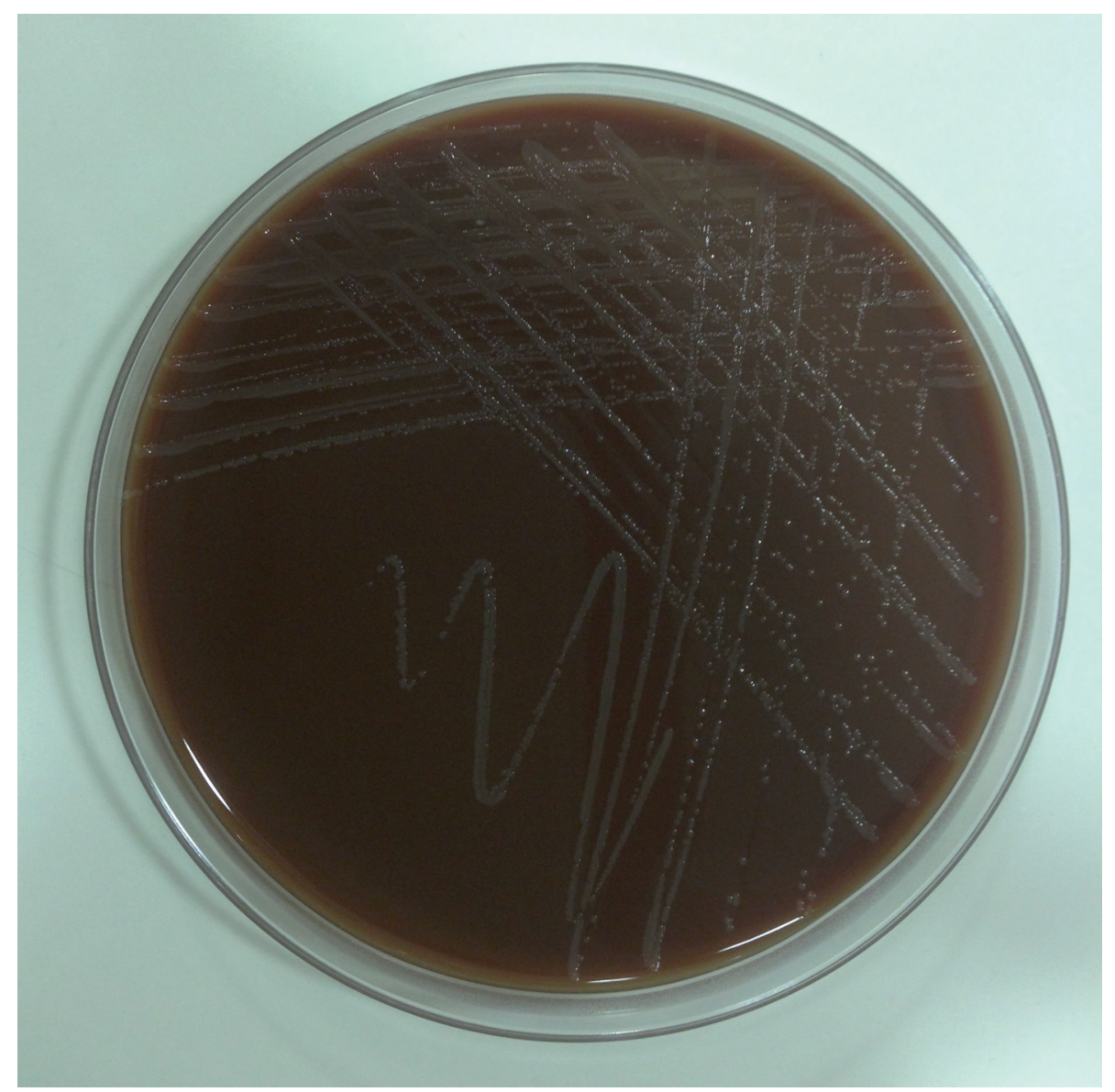

Figura 1. Colonias de Haemophilus influenzae en agar chocolate. 


\title{
Haemophilus influenzae
}

Haemophilus influenzae es una de las 8 especies de Haemophilus que residen como organismos comensales en faringe humana.

Es un coco bacilo gramnegativo pequeño que mide $0,2-0,3$ por $0,5-0,8 \mu \mathrm{m}$, inmóvil, no formador de esporas, perteneciente a la familia Pasteurellaceae. Está ampliamente distribuido y afecta exclusivamente a humanos.

Haemophilus influenzae requiere del punto de vista nutricional un medio complejo y factores de crecimiento que se encuentran presentes en los eritrocitos: factor $\mathrm{X}$ o factor termoestable del hierro, que suministran protoporfirinas (hemina) y factor $\mathrm{V}$ o factor termolábil (NAD o NADP).

Crece a $35-37^{\circ} \mathrm{C}$ en un $\mathrm{pH}$ óptimo de 7,6 en condiciones aeróbicas o con $5 \% \mathrm{CO}_{2}$. El medio de elección es agar chocolate que libera los factores $\mathrm{X}$ and $\mathrm{V}$ que necesita para su desarrollo. En la tinción de Gram pueden verse pleomórficos y gram variables. Se describe satelitismo, ya que crece alrededor de colonias de $S$. aureus hemolítico (fuente de factor V).

Las colonias tienen una forma convexa, circular, granular o transparente, levemente opaca; de $0,5-0,8 \mathrm{~mm}$ a las $24 \mathrm{~h}$ y 1-1,5 mm a las $48 \mathrm{~h}$. Las colonias de las cepas capsuladas son de mayor tamaño y de aspecto más mucoide, alcanzado los $3 \mathrm{~mm}$. Presenta un olor característico.

Se puede realizar biotipificación por la producción de indol, ureasa y actividad de la ornitina descarboxilasa. Fermenta glucosa y deoxiribosa, con producción de ácido, pero no gas, también lo hace con xilosa, pero no sucrosa, lactosa o manitol. Son catalasa y oxidasa positiva. Posee fosfatasa alcalina y son $\mathrm{H}_{2} \mathrm{~S}$ y esterasa negativa. Todas las cepas son $\alpha$ (PNPG) y $\beta$ glucosidasa positiva, así como $\beta$ galactosidasa (ONPG) positivas.

Presenta dos variedades: capsulado, en que se describen 6 serotipos designados con las letras "a" a la " $\mathrm{f}$ " basado en los polisacáridos de su cápsula y con capacidad de producir enfermedades invasoras y el no capsulado, no tipificable o no clasificable que coloniza la nasofaringe en $50-75 \%$ de niños sanos y adultos; ocasionalmente se aísla del tracto genital.

El CLSI recomienda el uso de HTM (Haemophilus Test Medium) en caldo o agar para testear la susceptibilidad. Se realiza una suspensión directa de la colonia equivalente a un $\mathrm{Mc}$ Farland 0,5 en $\mathrm{CO}_{2}$ durante $16-18 \mathrm{~h}$ a $35^{\circ} \mathrm{C} \pm 2^{\circ} \mathrm{C}$ en disco y en caso de dilución en caldo a $\mathrm{T}^{\circ}$ ambiental durante 20-24 h. La detección de $\beta$ lactamasas se realiza con test cromogénico, usando discos de nitrocefina. Se vigila sensibilidad a ampicilina, ampicilina/sulbactam, amoxicilina/ácido clavulánico, piperacilina/tazobactam, cefalosporinas, carbapenémicos, macrólidos y quinolonas.

\section{Referencias bibliográficas}

1.- McCrea K W, Xie J, LaCross N, Patel M, Mukundan D, Murphy T F, et al. Relationships of nontypeable Haemophilus influenzae strains to hemolytic and nonhemolytic Haemophilus haemolyticus strains. J Clin Microb 2008; 46: 406-16.

2.- Kilian M. A taxonomic study of the genus Haemophilus, with the proposal of a new species. J Gen Microbiol 1976; 93: 9-62.

3.- Chapter III: Haemophilus influenzae confirmatory identification and antimicrobial susceptibility testing. Perilla M, Ajello G, Bopp Ch, Elliot J, Facklam R, Knapp J, et al. Manual for the Laboratory Identification and Antimicrobial Susceptibility Testing of Bacterial Pathogens of Public Health Importance in the Developing World. CDC/WHO 2003. p 5-27.

\author{
Andrea Sakurada \\ Hospital Clinico Universidad de Chile

